\title{
The usage of a combined machine in the process of preparing the land for planting
}

\author{
$F$. Juraev ${ }^{1}, G$. KHamroyev ${ }^{1 *}, Z$. KHaydarova ${ }^{1}, I$. KHamroyev $^{1}, I$. Ibodov $^{1}$ \\ ${ }^{1}$ Bukhara Branch of the Tashkent Institute of Irrigation and Agricultural Mechanization Engineers, \\ Bukhara, Uzbekistan
}

\begin{abstract}
The existing traditional technologies of land preparation, such as leveling, chiseling, harrowing, mulching, and many other agro-technical measures performed by separate units, are labor-intensive, which costly and overspending on material costs, where fuel consumption is 78-86 liters per hectare. In the unit that prepares the lands, we are proposing planting in one pass, five agrotechnical tillage operations were carried out at one time, and 35-45 1 of fuel consumption was observed while each hectare of land was being tilled. Based on the research results on the efficiency of presowing tillage and the results of scientific research to increase the efficiency of this type of aggregates, an optimal variant of a combined aggregate is prepared and used for the direct preparation of lands for planting.
\end{abstract}

\section{Introduction}

One of the most pressing issues today is the creation of the necessary conditions for more sustainable development of agricultural production, improving the reclamation of lands, increasing their productivity, and, on this basis, increasing the productivity of agricultural crops, as well as improving the organization and financing of land reclamation [1].

Implementing quality tillage on irrigated lands is a guarantee of a rich harvest. To maintain and restore soil fertility, first of all, in the autumn season, to enrich the soil with humus, it is necessary to apply organic fertilizers and various organomineral composts. The cluster model is widely used in the production of agricultural products. In recent years, the volume of land allocated to cotton and textile clusters is $52 \%$ of the agricultural land allocated for this type of crop. At the same time, the lack of effective market mechanisms in state support of agriculture does not allow to increase the competitiveness of the sector.

These reforms require the mechanization of agriculture and deep processing of agricultural products by developing a wide range of modern financial services and increased access to quality agricultural machinery. The efficient use of land in agriculture provides for the preparation of quality seeds, the organization, and development of primary seed production of local and foreign selection varieties, including biotechnological varieties [2].

*Corresponding author: hamroyev1995@bk.ru 
Quality tillage in the short time before sowing is one of the main tasks to ensure high and stable yields of agricultural crops among complex agro-technical measures [3], [4], [5].

The specifics of pre-sowing tillage on irrigated lands in cotton-growing areas are divided into three zones according to natural-climatic and soil conditions, the mechanical components of the soil, tillage technology, machine types, and agrotechnical requirements. The third area, which accounts for 58 percent of the cotton area, includes lands that are difficult to cultivate and have varying degrees of salinity. This area includes lands in Central Fergana and below the second zone: Tashkent, Jizzakh, Samarkand, Syrdarya, Bukhara, Khorezm, Kashkadarya, and Surkhandarya regions of the Republic of Uzbekistan [6],[7],[8].

In the process of leveling the soil, the resistance of the levelers is high, and to reduce the resistance, special hydraulic cylinders are installed on the leveler and used.

Calculation and selection of hydraulic cylinders. The force acting on the hydraulic cylinder is determined by the following formula [9-10]:

$$
F_{\mathrm{ts}}=\frac{F_{\mathrm{i} . \mathrm{k}}}{\eta} \cdot\left(1+\frac{V_{1}}{g \cdot t}\right), N
$$

here: $F_{i . k}$ is the impact force of the work piece on the hydraulic cylinder stock, $\mathrm{N}$ $\mathrm{g}$ is acceleration of free fall of objects, $\mathrm{m} / \mathrm{s}^{2} / \mathrm{g}=9,81 \mathrm{~m} / \mathrm{s}^{2}$

$\mathrm{t}$ is acceleration time, $\mathrm{s}$

$\eta$ is the general F.I.K. of the cylinder.

$\mathrm{V}_{1}$ is the speed of movement of the piston under pressure, $\mathrm{m} / \mathrm{s}$

The diameter of the hydraulic cylinder piston:

$$
D=\sqrt{\frac{4 \cdot F_{i . k}}{10^{6} \cdot \pi \cdot \mathrm{P}}, M}
$$

here: $\mathrm{P}$ is fluid pressure in the hydraulic drive, $\mathrm{mPa}$

The diameter of the piston rod is calculated by the following formula:

$$
d_{\mathrm{sh}}=D \sqrt{1-\frac{V_{1}}{V_{2}}, \mathrm{M}}
$$

here: $V_{2}$ is return speed of piston, $\mathrm{m} / \mathrm{s}$

The wall thickness of the cylinder is calculated by the following formula:

$$
\delta_{t s} \geq \frac{D}{2} \cdot\left(\sqrt{\frac{[G]+P}{[G]-P}}-1\right), \mathrm{M}
$$

here: $[\mathrm{G}]$ is allowable tensile stress of cylinder material, $\mathrm{mPa}$

$\mathrm{P}$ is fluid pressure in the hydraulic drive, $\mathrm{mPa}$

The amount of liquid consumed for the cylinder is calculated by the following formula:

$$
Q=\frac{\pi \cdot D^{2}}{4} \cdot V_{1}, m^{3} / s
$$

The power of the hydraulic cylinder is calculated by the following formula:

$$
N=\frac{F_{\mathrm{ts}} \cdot V_{1}}{1000}, \mathrm{kVt}
$$

The inside diameter of the pipes supplying the fluid to the hydraulic cylinder is calculated by the following formula [11],[12]: 


$$
d_{\mathrm{k}}=\sqrt{\frac{4 \cdot Q}{\pi \cdot V_{3}}, \mathrm{M}}
$$

here: $\mathrm{V}_{3}$ is the flow rate of the liquid in the pipe,

Suppose the machine has several hydraulic cylinders that perform different functions. In that case, the amount and capacity of fluid consumed in each of these hydraulic cylinders is calculated separately by the above formulas. Based on these $\sum \mathrm{Q}_{\mathrm{gs}}$ and $\sum \mathrm{N}_{\mathrm{gs}}$ values, the hydraulic pump is selected from the table [13],[14].

The inside diameter of the steel pipes between the hydraulic pump and the liquid distributor is calculated by the following formula:

$$
d_{\mathrm{k}}^{1}-\sqrt{\frac{4 \cdot Q}{\pi \cdot V_{3}}}, \mathrm{M}
$$

here: $\sum \mathrm{Q}_{\mathrm{g}, \mathrm{s}}$ is the amount of liquid consumed in the whole hydraulic cylinder, $\mathrm{m}^{3} / \mathrm{s}$,

The thickness of the steel pipe wall is calculated by the following formula:

$$
\delta_{k}=\frac{P \cdot d_{k} \cdot k}{2[G]_{\mathrm{ts}}}, M \quad \delta_{k}^{1}=\frac{P \cdot d_{k}^{1} \cdot k}{2[G]_{\mathrm{ts}}}, M
$$

here: $\mathrm{P}$ is fluid pressure in hydraulic drive, $\mathrm{mPa}$

$\mathrm{k}$ is safety factor

$\mathrm{G}_{\mathrm{ts}}$ is allowable tensile strength of the material, $\mathrm{mPa}$

Calculation and selection of hydraulic motors.

When choosing a hydraulic motor, it is necessary to find the amount and power of fluid consumed in it [15],[16],[17],[18].

The power of the hydraulic motor is calculated by the following formula:

$$
N_{\mathrm{G} . \mathrm{M}}=\frac{\pi \cdot n \cdot \mathrm{M}_{\text {ay }}}{3 \cdot 10^{4} \cdot \eta}, k V t
$$

here: $\mathrm{n}$ is number of revolutions of the hydraulic shaft, ayl $/ \mathrm{min}$

$\mathrm{M}_{\mathrm{ay}}$ is torque of hydraulic shaft, $\mathrm{Nm}$.

$$
M_{a y l}=9554 \cdot \frac{N_{i s h}}{i_{\text {um }} \cdot n_{\text {ish }} \cdot \eta_{i s h}}, N m .
$$

here: $\mathrm{N}_{\text {ish }}$ is power of working equipment, $\mathrm{kVt}$

$\mathrm{n}_{\mathrm{ish}}$ is the number of revolutions of the work piece, ayl $/ \mathrm{min}$.

$\eta_{\text {ish }}$ is do not drive F.I.K.

$i_{u m}$ is total transfer rate.

The fluid consumed by the hydraulic motor is calculated by the following formula:

$$
Q=\frac{\pi \cdot n \cdot \text { May }}{3 \cdot 10^{7} \cdot R \cdot \eta}, m^{3} / s
$$

here: $\mathrm{N}_{\text {ish }}$ is the number of revolutions of the hydraulic shaft, ay $/ \mathrm{min}$ $\mathrm{M}_{\mathrm{ay}}$ is torque of the hydraulic motor shaft, $\mathrm{Nm}$.

$R$ is fluid pressure in the hydraulic drive, $\mathrm{mPa}$

$\eta$ is hydraulic motor F.I.K.

$\mathrm{Q}$ and $\mathrm{N}$ depending on the values - the hydraulic motor is selected from the table.

The volume of the liquid tank of the hydraulic drive is calculated by the following formula [19],[20],[21],[22],[23]: 


$$
V_{\mathrm{b}}=\frac{1}{10^{3}} \cdot \sqrt{\left(\frac{\theta}{t_{2}-t_{1}}\right)^{3}}, \mathrm{M}^{3}
$$

here: $\theta$ is cythe amount of heat transfer of the load, $\mathrm{kkal} / \mathrm{soat}$;

$N_{\mathrm{y}}$ is the lost power of the hydraulic drive, $\mathrm{kVt}$.

$$
N_{y}=\frac{\mathrm{P} \cdot \sum \mathrm{Q}_{\mathrm{yu}}}{60} \cdot(1-\eta), k V t
$$

here: $Q_{\mathrm{yu}}$ is the amount of fluid consumed in the simultaneously operating networks of the hydraulic drive, litr/min

$\eta$ is mechanisms F.I.K.

$\mathrm{K}_{\mathrm{v}}$ is machine time utilization factor

$\mathrm{t}_{1}$ is ambient temperature, ${ }^{o} \mathrm{C}$

$\mathrm{t}_{2}$ is the temperature at which the liquid is allowed to heat up, ${ }^{\circ} \mathrm{C}$

The design solution of the combined machine, their location and size, natural climatic conditions of the area, physical, mechanical and technological properties of the cultivated soil, agrotechnical requirements for tillage technology, feasibility and feasibility of simultaneous technological operations and energy base (applied tractor power, constructive and operational advantages).

\section{Materials and Methods}

The results of the field survey conducted at Muhammad Ismat Farm, Rabotkalmoq Farm, Bukhara District, showed that the unit's high efficiency in preparing the land for planting, and in most cases the simultaneous operations, allows for better soil preparation in a shorter period. This allows the soil to retain moisture and the seeds to be sown in freshly treated moist soil at specified intervals, which in turn serves to increase crop yields.

Simultaneous carrying out of technological operations sharply reduces the number of passes of the unit on the field and sharply reduces the impact of tractor walking systems. When the operations are carried out separately, up to $80 \%$ of the field, the surface layer is compacted by the tractor wheel, of which up to $30 \%$ is affected once, up to $20 \%$ twice, up to $15 \%$ three times, and up to $5 \%$ four times.

When operations are combined, the number of transitions and the compacted surface is reduced by 2-3 times, and the impact of adverse weather conditions is reduced. Economically, the cost of preparing the land for planting is saved, and the loss of extra time is prevented.
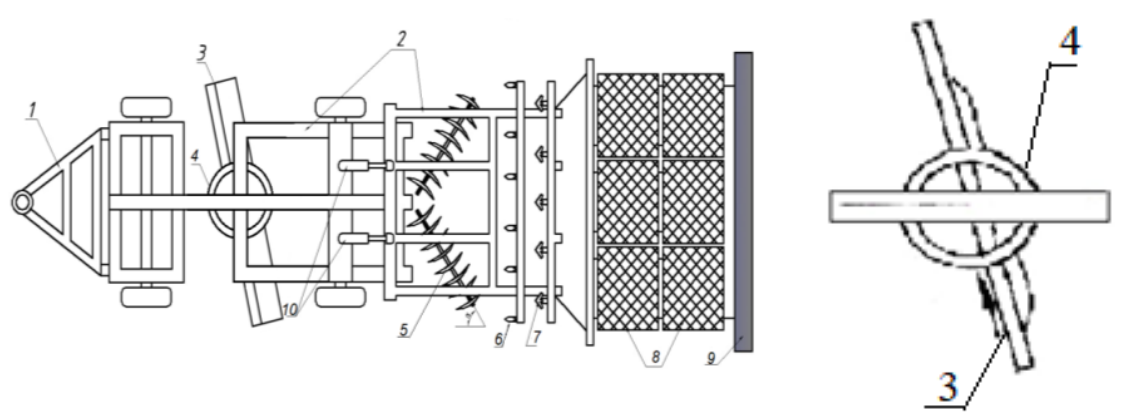
Fig. 1. Schematic of a machine that prepares the soil for planting.

1 is tie device, 2 isframe, 3 is leveling, 4 is rotating platform, 5 is disc harrow, 6 is softener, 7 is foot, 8 is toothed harrow, 9 is break (compactor), 10 is hydraulic cylinder.

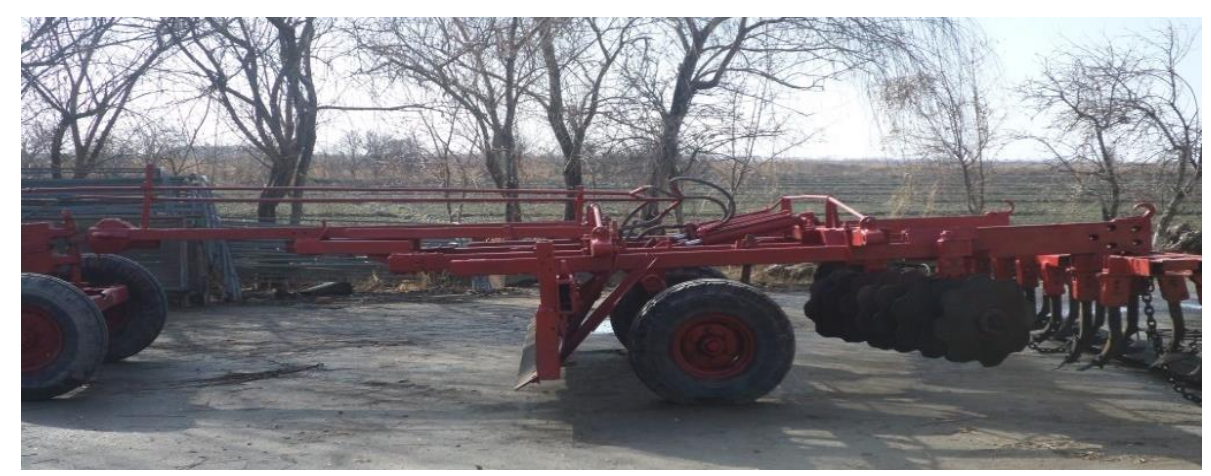

Fig. 2. Side view of the combined machine

\section{Results and Discussion}

In the conditions of the Bukhara region, when preparing the soil for planting, the aggregate is applied to the soil at least four times before burying the seeds, and each hectare of land consumes a total of 78-86 liters of fuel. In the universal machine, we offer, five agrotechnical treatments are carried out at once, consuming 35-45 liters of fuel per hectare of cultivated land. Obviously, cost-effectiveness is achieved by saving these costs; when the field experiment in the Bukhara region, positive economic efficiency was achieved. Another issue was the scientific task of scientifically substantiating the increase in efficiency by using a common frame and hydraulic system to transport a universal machine and reduce the overall resistance.

\section{Conclusions}

1. It is known from the existing recommendations in the process of preparing arable lands for sowing in the Bukhara region that, depending on the conditions for the preparation of arable land for planting, various technological operations must be performed. For this purpose, the field is often introduced and widely used. As a result, under the influence of tractor and machine wheels, the soil is over-compacted, the soil fraction is disturbed, and the water-absorbing properties of the soil deteriorate.

Repeated application of aggregates to the field, especially in arid climates, can cause great damage in soils with low humus content in the soil and mechanical effects can break down organic matter and evaporate along with moisture or wash away with water. Therefore, the method of minimum field cultivation is widespread and fast all over the world, which requires the efficient use of this type of machine.

2. In the conditions of the Bukhara region, the effective use of combined aggregates in the preparation of lands for sowing is achieved through the use of the following aggregate, which is recommended to increase crop yields.

3. The application of new technologies in field farming, the use of energy-saving universal machines, the introduction of resource-saving technologies in agriculture, high yields from irrigated crops will improve the economy of our country and the livelihood of our people. 


\section{References}

1. Bazarov D., Uralov B., Matyakubov B., Vokhidov O., Uljaev F., Akhmadi M. The effects of morphometric elements of the channel on hydraulic resistance of machine channels of pumping stations, IOP Conference Series: Materials Science and Engineering, 869:072015.,DOI: 10.1088/1757-899X/869/7/072015. (2020).

2. Mamatov F., HudoyorovB.K, Haydarov E.K, Kuziyev U.. Yerni tayyorlashda yangi usul afzalliklari [Advantages of the new method of land preparation], O'zbekiston qishloq xo'jaligi. - Toshkent, 10. pp.16-17. (2003).

3. Mamatov F.M.. Qishloq xo‘jaligi mashinalari [Agricultural machinery] Toshkent: O'zbekiston - (2007)

4. Mamatov F.M. Теория и расчет плоских дискових ножей селскохозяствснных машин. [Theory and calculation of flat disc knives of agricultural machines]. Qarshi: Nasaf, (1992).

5. Khamidov M., Matyakubov B., Isabaev K. Substantiation of cotton irrigation regime on meadow-alluvial soils of the Khorezm oasis, Journal of Critical Reviews, ISSN2394-5125, 7, (4), pp. 347 - 353. (2020).

6. Matyakubov B. How efficient irrigation can ensure water supply in the Lower Amudarya basin of Uzbekistan, International Water and Irrigation, 23 (3), pp. 26-27. (2003).

7. Uralov B., Xidirov S., Matyakubov B., Eshonkulov Z., Norkulov B., Gayur A. River channel deformations in the area of damless water intake, FORM-2020, IOP Publishing, IOP Conf. Series: Materials Science and Engineering 869 072014., doi:10.1088/1757-899X/869/7/072014 . (2020).

8. Nazaraliyev D.V., Jumabaeva G.U, Statistical estimation of the feed source and hydrological regimes of the piskom river. International Journal of Engineering and Designing Innovation, 2582-0788. (2019).

9. Matyakubov B., Begmatov I., Raimova I., Teplova G. Factors for the efficient use of water distribution facilities, CONMECHYDRO - 2020, IOP Conf. Series: Materials Science and Engineering 883012050 doi:10.1088/1757-899X/883/1/012050. (2020).

10. Matyakubov B., Mamazhonov M., Teplova G, Shakirov B., Shakirov B. Forebays of the poligonal cross - section of the irrigating pumping station, CONMECHYDRO 2020, IOP Conf. Series: Materials Science and Engineering 883012050 doi:10.1088/1757-899X/883/1/012050. (2020).

11. Matyakubov B., Begmatov I., Mamataliev A., Botirov S., Khayitova M, Condition of irrigation and drainage systems in the Khorezm region and recommendations for their improvement, Journal of Critical Reviews, ISSN- 2394-5125, 7, (5), pp. 417 - 421. (2020).

12. Matyakubov B.Sh., Mamatkulov Z.J., Oymatov R.K., Komilov U.N., Eshchanova G.E , Assessment of the reclamation conditions of irrigated areas by geospatial analysis and recommendations for their improvement, InterCarto. InterGIS GI SUPPORT OF SUSTAINABLE DEVELOPMENT OF TERRITORIES Proceedings of the International conference. 26, (3)- p. 229 - 239. (2020).

13. Begmatov I.A., Matyakubov B.Sh., Akhmatov D.E., Pulatova M.V. Analysis of saline land and determination of the level of salinity of irrigated lands with use of the geographic information system technologies, InterCarto. InterGIS GI SUPPORT OF SUSTAINABLE DEVELOPMENT OF TERRITORIES 
14. KHamroyev G.F, To'ayev S.S, Effisient usa of preparation aggregates for planting lands in a single pass vitx a straightening torsion vork [Эффисиент усе оф препаратион аггрегатес фор плантинг ландс ин а сингле пасс wитх а страигхтенинг торсион шорк] // матеріали міжнародної наукової конференції. (Т. 1), 12 червня, рік. Київ, Україна: МЦНД. pp 119-121. (2020).

15. KHamroyev G.F, To'rayev S.S. Vibor rabochego oborudovaniya gidrotsilindra, ustanovlennogo v kombinirovannom agregat Selection of working equipment for a hydraulic cylinder installed in a combined unit], Electronic journal «Столица Науки» МАЙ 5 (22) pp.96-103.

16. Nurov KH, KHamroyev.G.F, Sirojev.J, Zayniyev.O, Mardonov.M, Preimushestva texnologii primeneniya posevnix mashin universal $\mathrm{v}$ Buxarskoy oblasti [Advantages of technology of application of seeding machines universal in Bukhara region], The Way of Science. 12 (70). pp. 62-64. (2019).

17. Khamidov M.Kh., Juraev F.U. The device and principles of operation of the drainage mole gun. Irrigatsiya va Mellioratsiya. -Toshkent, 1 (7). p 12. (2017).

18. Mamatov F.M. Batirov Z.L. Khalilov M.Kh. Kholiyarov E.B. Three-tier fertilizer application with a fertilizer-distributor subsoiler. Agricultural Machines and Technologies. 13 (4). pp.48-53. (2019)

19. Rahmatov M., Matyakubov B., Berdiev M. Maintainability of a self-pressurized closed irrigation network, IOP Conference Series: Materials Science and Engineering, 1030 012170 IOP Publishing doi:10.1088/1757-899X/1030/1/012170. (2021).

20. Hamidov, A., Khamidov, M., Ishchanov, J. Impact of climate change on groundwater management in the northwestern part of Uzbekistan, Agronomy, 10 (8), p 1173. (2020).

21. Khamidov, M.K., Khamraev, K.S., Isabaev, K.T. Innovative soil leaching technology: A case study from Bukhara region of Uzbekistan, IOP Conference Series: Earth and Environmental Science, 422 (1), 012118, (2020).

22. Khamidov, M., Khamraev, K., Azizov, S., Akhmedjanova, G. Water saving technology for leaching salinity of irrigated lands, A case study from Bukhara region of Uzbekistan. Journal of Critical Reviews, 7 (1), pp 499-509, (2020).

23. Balla, D., Omar, M., Maassen, S., Hamidov, A., Khamidov, M. Efficiency of duckweed (Lemnaceae) for the desalination and treatment of agricultural drainage water in detention reservoirs. Environmental Science and Engineering (Subseries: Environmental Science), (202979), pp 423-440, (2014). 